\title{
Castle Garth in Newcastle (UK): processes of transformation, integration and discharge of a fortified complex in an urban context
}

\author{
Francesco Novelli \\ Dipartimento di Architettura e Design - Politecnico di Torino, Turin, Italy, francesco.novelli@ polito.it
}

\begin{abstract}
Castle Garth is the name of the fortified area once enclosed within the castle walls. In the fifteenth century Newcastle became a county in its own right, however, the Garth, being within the castle walls, remained part of the County of Northumberland. The Great Hall, a building separate from the Castle Fortress (the "Keep"), which in later years became known as the "Old Moot Hall", was used by courts that sat at regular intervals in every county of England and Wales. The Fortress then became a prison for the County and was used as such until the early nineteenth century.

Beginning in the fifteenth century, unlicensed traders, taking advantage of the fact that the city authorities had no jurisdiction over the Garth area, settled there with their commercial activities. From the time of Charles II (1630-1685), the area then became famous for its tailors and shoemakers, who grew particularly abundantly on the path known as "Castle Stairs".

In 1619 the fortified complex was rented by James I to the courtier Alexander Stephenson, who allowed the civilian houses to be built inside the castle walls. After the civil war, new houses were added until, towards the end of the eighteenth century, Castle Garth had become a distinct and densely populated community, with a theater, public houses and lodgings.

The main urban transformations were started in the early nineteenth century with the construction of the new Moot Hall called County Court. From 1847 to 1849 the fortified enclosure was partially compromised by further intersections with the infrastructure for the construction of the railway viaduct, thus interrupting direct access from the Castle guarding the Black Gate.

Despite the development of the contemporary city has affected the preservation of the ancient fortified palimpsest, a strong consolidated link is still maintained by the sedimentation of values of material and immaterial culture. The proposed contribution intends to present this process of integration between fortified structure and city highlighting today the state of the art, the conservation, restoration and enhancement initiatives undertaken in the last forty years. ${ }^{1}$
\end{abstract}

Keywords: Castle Garth, fortifications, preservation, reuse.

\section{Introduction}

"Between ca. 1600 and the present day, the royal stronghold of the middle ages underwent dramatic change, from a dilapidated wreck of fortifications the castle and its precincts became a populous and independent township within the town of Newcastle. At the height of its development, before ca. 1810, the site of the castle (known as the Castle Garth), contained at least three public houses, a non-conformist chapel, a theatre, a numerous shops and houses" (Nolan, 1990, p. 79).

The life of the Garth's inhabitants was a colorful one. This was not the location for genteel society but one where people often on the lowest social 
rung lived and worked. The Newcastle Courant is a primary source of reports of murders, assaults, robberies and willful damage is littered with preferences to incidents which happened in the Garth to or by its inhabitants. Today, there is a little evidence of the domestic life which once typified the Garth. From a royal holding, the Garth became densely populated over 250 year period. Its location, its physically small area and its earthy character meant that it often missed out on social and technological improvements which were happening elsewhere in Newcastle (and indeed making the town exceedingly prosperous in the process). The coming of the railway signaled the end of the Garth as a "town within a town" and houses started to be pulled down, being little more than a slum. The Keep ${ }^{2}$ was already established as a place of historical importance and by 1884 the Black Gate was open as a museum.

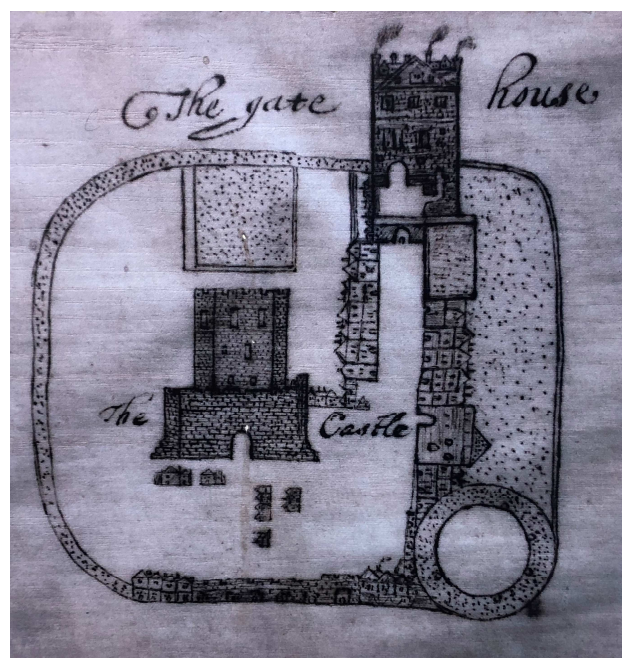

Fig. 1. Detail map showing The Black Gate in 1638.

\section{Castle Garth}

What is the Castle Garth? Quite a restricted area, mainly regarded as the area enclosed by the defensive curtain wall of the Castle (the "Keep", Fig. 1). In records, the name often referred to a much wider area, the so-called "mantle wall" (of the bank between the Castle and the quayside, Fig. 2). When the town walls were completed in the mid-fourteenth century, the Castle lost of its military significance and it became a place of dump and rubbish. The Crown only had a passing interest and by the 1580 the castle was described as "old and ruinous". By the end of the sixteenth century the castle's ditch was filled in with rubbish and it was likely that some houses had been built around the Keep.

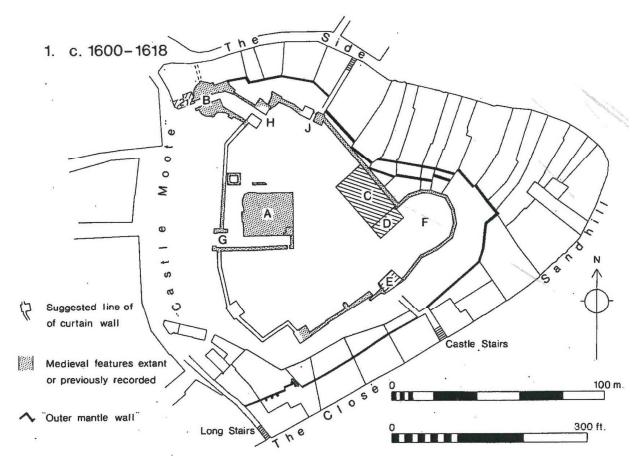

Fig. 2. Castle Garth, 1600-1618 (Nolan, 1990, p. 84).

James I didn't want to give out the vibes that he was holding onto the castle as an insurance policy in case his English crown didn't work out, so he leased it out. This was really important because it was the first time ever it had happened, that it had come out of direct crown control. First lease was to the Incorporated Company of Tailors, then it went to one of his loyal Scottish supporters, Alexander Stephenson. Page of the Bedchamber (he was unflatteringly referred to as "the royal stool"), he started his lease in April 1619. This was for all the area inside the castle apart from the Keep, Moot Hall and Gaoler's House. These remained directly with the crown. Stephenson seemed to have encouraged housebuilding in the Garth in a bid to increase his own income from rents, he also had started to reconstruct the gatehouse to use as domestic dwelling.

There seems to have been little restriction over the size or location of the plots for the first house-builders. Access into and around the Garth tended to determine where people built. A map of the town's defenses during the civil war show "the Gate House" with smoke coming out of its chimneys (suggesting a domestic dwelling by then) and parallel rows of three storey terraced houses leading from the back of the gate- 
house. The right hand row of houses leading from here seem to have held the same plot right up until the coming of the railway (where they can be seen in some of the 1880s photos with the name Dog Leap Stairs on the right, showing where the corner of the terrace was).

The 1620 Royal Survey of this crown land lists ten houses and two gardens. There were a further 19 gardens and "waste lands" on the slope of the castle towards the river. The Moot hall was used for the Court Sessions of Nurthumberland before 1600 for sure, evidently a medieval structure which was remodeled in the Jacobean period. Used for regular sittings of the quarterly assize sittings and for matters relating to the county of Northumberland.

During the civil war, the Garth and the castle area reverted to the city (relating to Patrick's Black's estate claims) and then back to the crown on the Restoration. The Corporation fought hard to retain its lease, which came with the royal license (Mackenzie, 1827, pp. 89-104).

The second half of the seventeenth century saw huge expansion in the Garth, in the context of security as to political situation. Some houses had been pulled down in the civil war to create or reinforce defenses, but once this was no longer needed, building houses forged ahead. Lots of houses created to the south of the Garth, also public building. John Pickells infact is recorded as the occupant -he was a vintner-, presumably running the precursor to the Two Bulls Heads pub in the Black Gate (Fig. 3).

The eighteenth century saw the rapid development of the Castle Garth as a community of tradesman, their workmen and tenants. By 1780 the hole area was crowded with buildings and yards. It remained this way for another hundred years plus -until the railway- related clearances and general improvements of the mid to late nineteenth century. The leasehold was once again with the corporation who now faced claims from tenants for repairs. Lots of references to dilapidated houses and disputes as to possession of some properties which were decaying. About 1787-1789, two public houses were in the Black Gate, one called the Blue-bell and one other unnamed, run by John Fife. By
1790 the Blue-bell had vanished from the records and Fife was now publican of the Two Bulls Heads pub (Fig. 4).

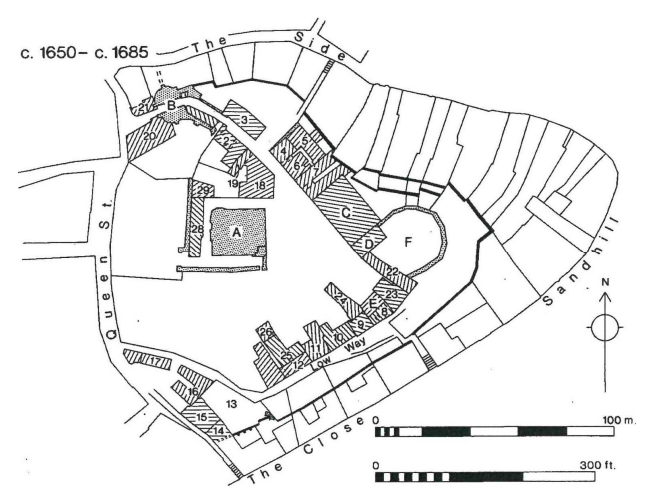

Fig. 3. Castle Garth, 1618-1649 (Nolan, 1990, p. 85).

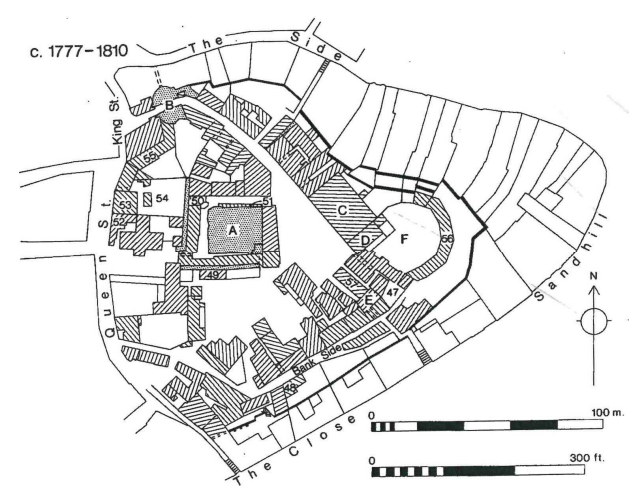

Fig. 4. Castle Garth, 1777-1810 (Nolan, 1990, p. 98).

The row of houses between the back of the Black Gate and Fog Leap Steps were in the possession of Elizabeth Isle and comprised 3 shops, 12 rooms, six garrets, a stable and a garden behind. All in a space not more that 20 feeth deep! Many of the houses in the Garth re-used earlier structures where expedient. This made sense, especially if the wall was solid medieval wall. For example, the holes in the medieval wall running south from the Black Gate can clearly be identified as joist holes for the shop immediately adjacent to the archway through. Dog Leap Stairs. What's in a name? "Dog loup" is a dialect term for "the narrow passage between two adjoining but detached houses". It indicates that sense houses were very close together. Indeed, a 1704 boundary dispute refers to a boundary as "an old 
wall or dog leap [...]" (Fig. 5) (Nolan, 1990, p. $85)$.

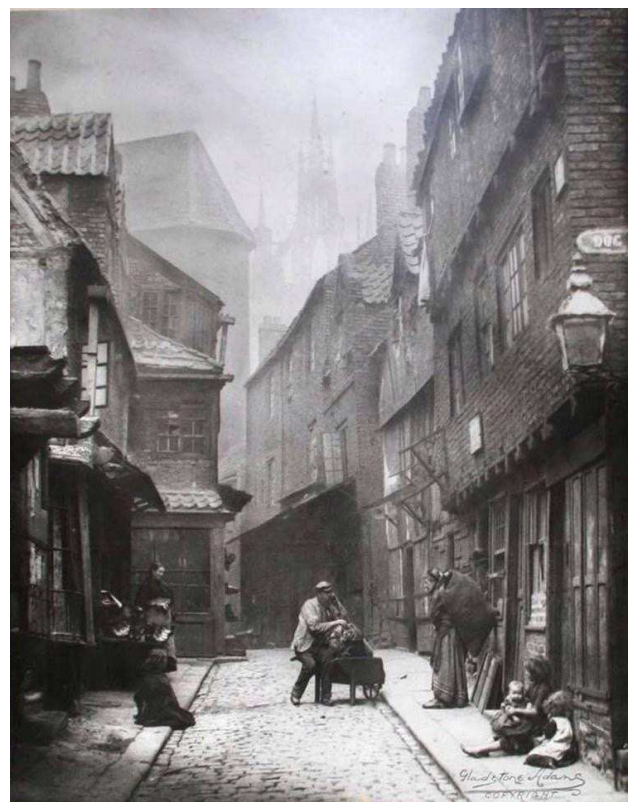

Fig. 5. Black Gate, close to Dog Leap Stairs (Bills, 1890).

In this period the Moot Hall continued as a court building for the County of Northumberland whilst also doubling up as a theatre which itinerant companies rented out for short seasons. By the 1788 the Theatre Royal on Grey Street had been constructed and this function of the Moot Hall lapsed.

By 1790 , an observed noted that the area around the Keep was "a very nasty state, there being many pigstyes, dunghills ans receptacles of filth thereabouts [...]". By 1746 the whole of the castle mound was enclosed by buildings (Fig. 4).

From mid-seventeenth century the Keep was only occasionally used to confine felons. There was a row of tenements called "Cloggers Row" butting up to its eastern side. The basement of the Keep was used as a beer cellars for the Three Bulls Heads just to the north; access to the cellars was gained through one of the chapel windows. The little room at the top of the Keep's stairs was also used as a shop by a currier (a leather-finisher). This was the time when there were plans to lease out the Keep as a windmill base.

By the beginning of the nineteenth century the Garth was full-to-bursting (Fig. 6): there were shops galore and more than 50 houses which several hundreds of people. Much of the Garth was still under lease but the leaseholder was a Londoner who was considering it expensive to maintain the increasing number of properties. $\mathrm{He}$ sold lots off to the Corporation who subdivided already full houses, effectively creating squalid tenements blocks. The Black Gate was a shadow of its former self, with missing window glass, pock-marked elevations where structural timbers from adjoining properties had been inserted and the whole structure was almost swallowed up by buildings clinging to its sides. By the 1851 census, more than 12 families of 60 people were crammed into its space (Fig. 7).

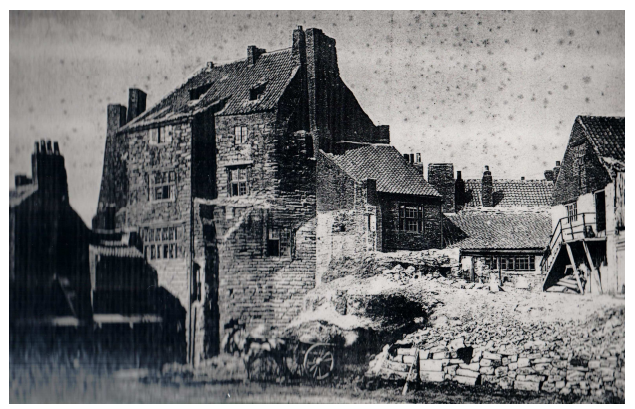

Fig. 6. The Black Gate (Private collection, 1846).

The Moot Hall was remodeled as the new County Courts for Northumberland. In 1845 The Newcastle and Bewick Royal Company began to acquire numerous properties in the Garth, along the route proposed for the extension to the north of the railway line, thus initiating a broad plan to demolish the present houses. At the completion of the railway line in 1849 , only small groups of buildings had survived and the Garth had been fragmented into three distinct areas. To the northeast of the viaduct only a few buildings remained, including the "Two Bull's Heads" which continued to operate until 1871, after which part of the building remained in use as a stone shop acquired by Walker, Emley and Beall, stonemasons of medieval buildings. 


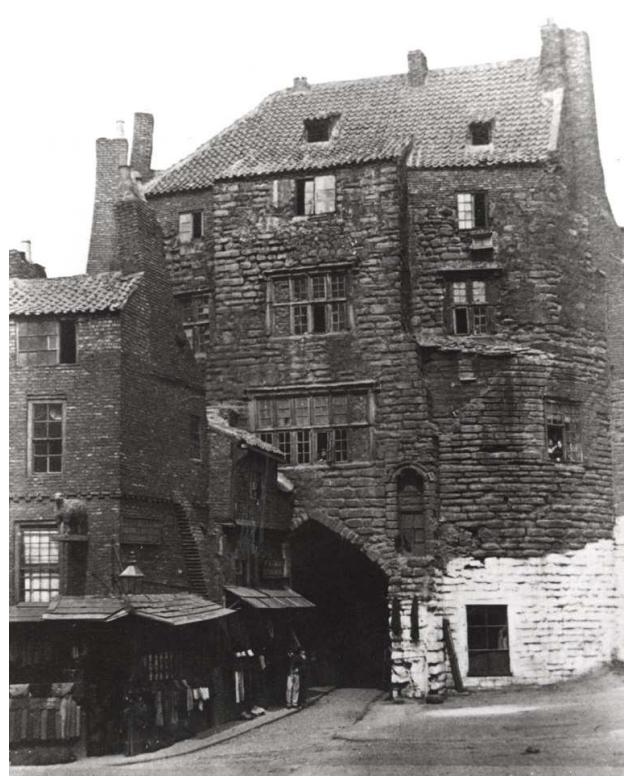

Fig. 7. The Black Gate (Newcastle Library, 1863).

The Black Gate was subject to many discussions within the Corporation and many felt that it should be torn down, such was its ruinous state. It was finally reprieved with the force of the Society of Anriquaries and the Duke of Northumberland. The matter was referred to the Finance Committee of the Corporation and eventually in 1883 the Society took up the lease (The Black Gate museum was opened in Jannuary 1884). Gradually the rest of the Garth was cleared and between 1847 and 1929 most of the houses in the Garth and crowding up to the Black Gate were demolished (Fig. 8). Between 1881 and 1896 new housing and construction works were started and completed. In particular, the demolition of buildings between the Black Gate and the Dog Leap Stairs began in 1892-1894 to expand the railway route. The Dog Leap Stairs themselves were buried with the extension of the viaduct (Fig. 9). The evacuation of the Garth has continued to this day. Since 1960, archaeological excavations have unearthed important portions of the medieval fortress previously hidden by leaning houses. Occasional fragments of brick walls and housings for the beams of the roofs and floors still characterize the ancient walls, evident memory of three centuries of domestic life within the perimeter of the Castle.

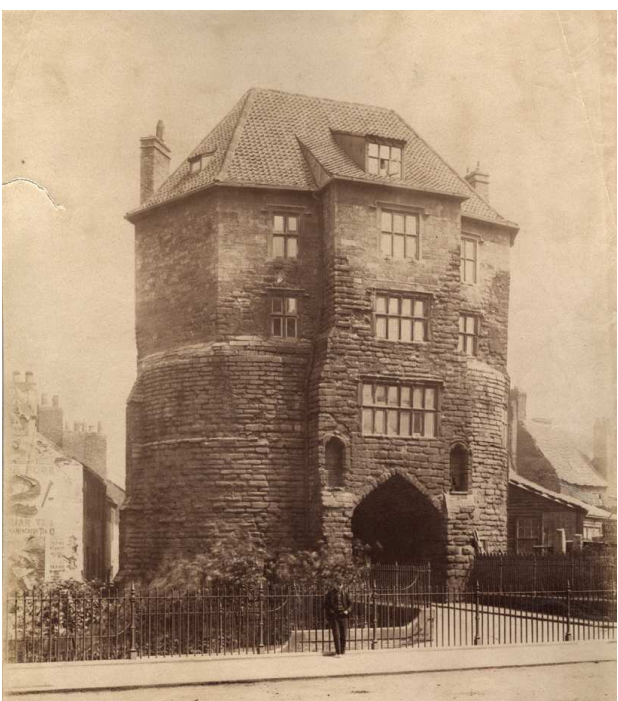

Fig. 8. The Black Gate (Newcastle Library, 1900).

\section{New lights on Black Gate: from the refur- bishment of the museum to the accessibility project}

The progression of archaeological investigations on the site in the last twenty years have brought important elements of knowledge but always connected with the medieval structures of the ancient complex ${ }^{3}$. On the other hand, the enhancement of the heritage of material and immaterial culture linked and developed around the fortress of which we spoke earlier was a little penalized. The current stays connected to the history of Garth are not wide enough to allow an obvious and immediate reading; the published historical studies have instead carefully reconstructed this important and very unique ecosystem that has characterized the history of the city of Newcastle.

The activity carried out by the Society of Antiquaries ${ }^{4}$ has certainly contributed -from its establishment on the premises of the Black Gateto consolidating an attitude of protection and widespread attention to the Castle Garth complex, or at least to what it is remained after the demolition and thinning work started with the construction of the railway line (1849). The awareness of the strong value of memory represented by the legacy constituted by the rich documentary heritage that bears witness to the vital- 
ity of the community gathered around the Garth has prompted, in recent years, the city of Newcastle to rethink the enhancement of the site. The project (2014-2017) was led by a partnership formed by City Council, the Cathedral and the Society of Antiquaries of Newcastle Upon Tyne. The restoration project and new museum set-up has also provided for a contemporary addition: an external lift, mitigated by wooden sipes to better match the ancient stone building reached through a system of ramps that makes the three floors of the new museum, the reception, the bookshop and the toilets. The highly educational identity of the new museum restores visibility to a wide audience of the complex and layered life of Garth between commerce, residence and malfeasance.

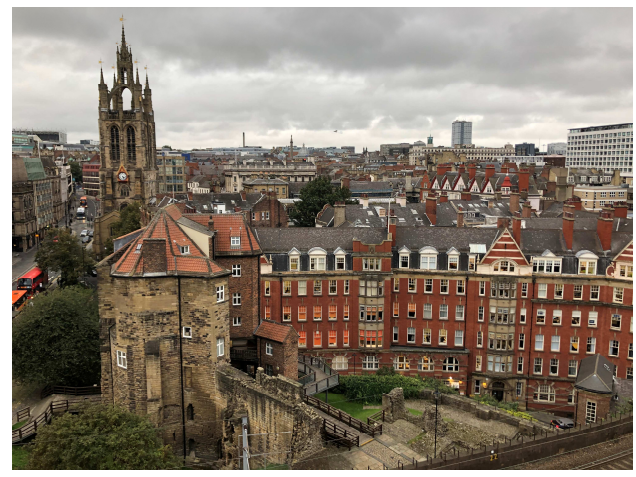

Fig. 9. The Black Gate and railway (2019).

The recent intervention of restoration and refunctionalization can be affirmed to have reached the goal of regenerating the threads of the history of a heritage, strongly defended and "protected" at the end of the nineteenth century which had physiologically suffered from the antiquity of museum exhibits and cultural proposals in the course of the twentieth century and which is now presented in the twenty-first century with a renewed proposal and above all intended for a wide audience thanks to its complete accessibility (Figs. 10-13).

\section{Notes}

${ }^{1}$ I would like to thank David Silk (Learner Officer_The Heart of the City Partnership, Newcastle Castle) for research collaboration. See al- so http://www.newcastlecastle.co.uk/home October 2019).
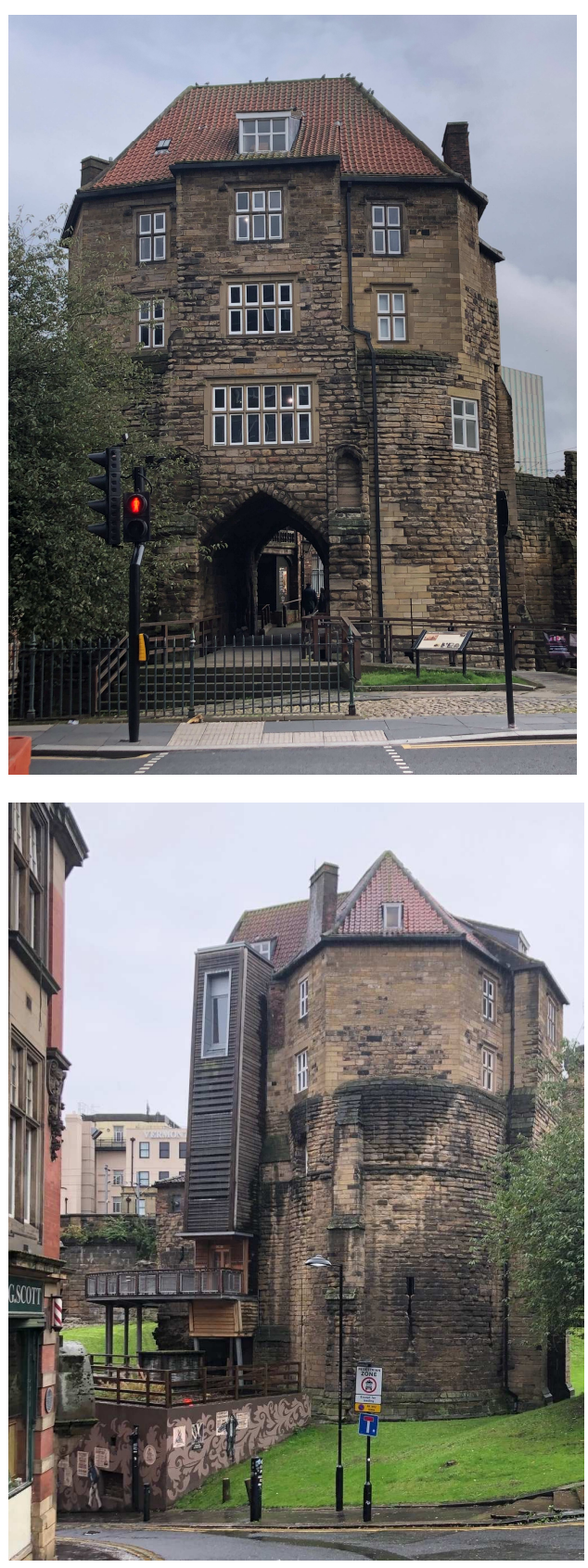

Figs. 10-11. The Black Gate (2019).

2 The castle, called The Keep, was heavily remodeled in the Victorian age with replacement 
of materials and significant reintegration of the missing fortified structures. Today it is an integral part of the museum complex called The Castle Keep, Castle Garth of the city of Newcastle Upon Tyne. The Castle Garth complex is a Scheduled Monument, No. SM32753, HA1620126, Historic Buildings and Monuments Commission for England.

${ }^{3}$ Please refer to the results of the recent archaeological excavation campaign conducted in the Ice House (Pit Room), The Keep, Castle Garth, Newcastle. Excavation conducted by Northern Counties Archaeological Services, August 2017.

${ }^{4}$ For more information on the Society's activity and on the important book collection, see also www.newcastle-antiquaries.org.uk (12 October 2019).

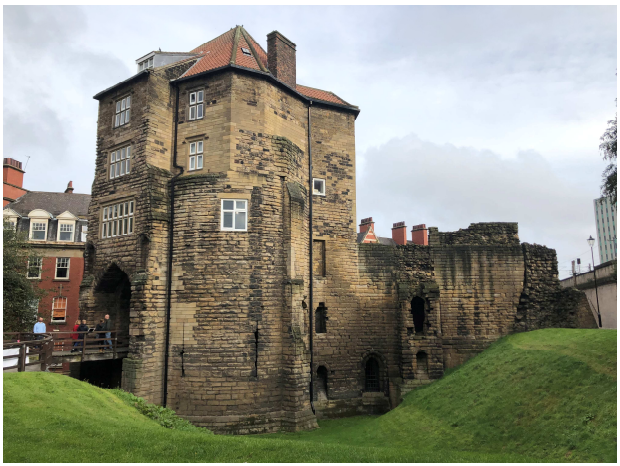

Fig. 12. The Black Gate (2019).

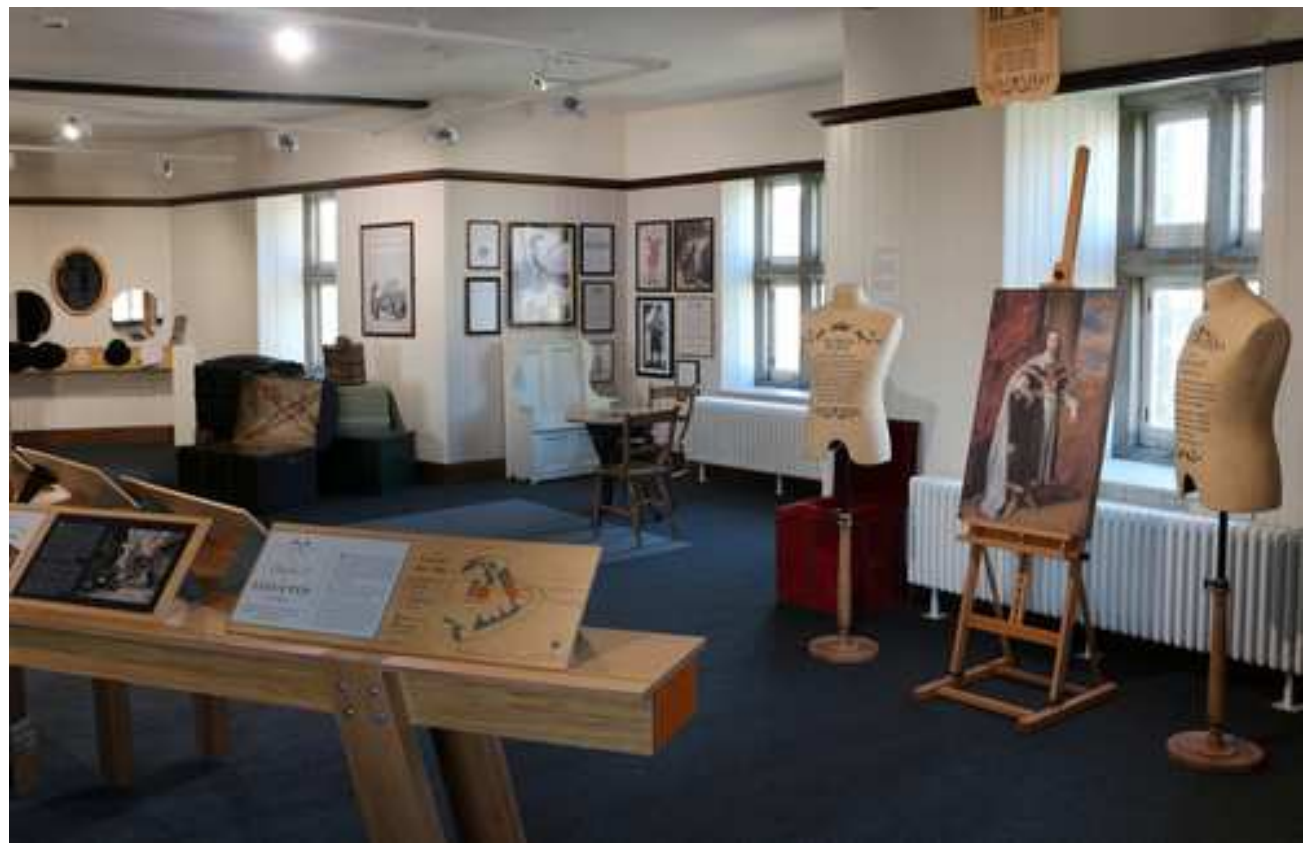

Fig. 13. Inside Black Gate museum (James Manson, 2005).

\section{Bibliography}

Brewis, P. (1922). A Guide to the castle of Newcastle - Upon - Tyne, Part II, The Black Gate museum and Heron Pit, Printed by T \& G. Allan, Newcastle Upon Tyne.

Bruce, J.C. (1847). A Guide to the Castle of Newcastle Upon Tyne, Hamilton Adams \& Co., London.

Mackenzie, E., ed. (1827). "Ancient Fortifications and Buildings", in Descriptive and Historical account of the town and the county of Newcastle Upon Tyne, including the borough of Gateshead, Newcastle Upon Tyne, vol. I, pp. 89-104. 
McCombie, G. (2009). Newcastle and Gateshead, Yale University Press, New Heaven and London, London, pp. 62-69. Nolan, J. (1990). "The Castle of Newcastle Upon Tyne after c. 1600", Archaelogia Aeliana, Miscellaneous Tracts relating to Antiquity, 5, XVIII, The Society od Antiquaries of Newcastle Upon Tyne, Newcastle, pp. 79-126. 